\title{
A Study on The Biomass Energy Potential of Turkey: Example of Wood Pellets
}

\author{
Devlet TOKSOY ${ }^{1}$ Semra COLAK ${ }^{2} \quad$ Mahmut M. BAYRAMOĞLU ${ }^{1 *}$ \\ ${ }^{1 *}$ Karadeniz Technical University, Faculty of Forestry, Department of Forest Engineering, Kanuni Campus, Trabzon, Turkey \\ ${ }^{2}$ Karadeniz Technical University, Faculty of Forestry, Department of Forest Industry Engineering, Kanuni Campus, Trabzon/Türkiye
}

How to cite: Toksoy, D., Çolak, S., Bayramoğlu M.M. (2020). A Study on The Biomass Energy Potential of Turkey: Example of Wood Pellets. J. Anatolian Env. and Anim. Sciences, 5(5), 867-867.

Atıf yapmak için: Toksoy, D., Çolak, S., Bayramoğlu M.M. (2020). Türkiye’nin Biyokütle Enerji Potansiyeli Üzerine Bir Araştırma: Odun Peleti Örneği. Anadolu Çev. ve Hay. Dergisi, 5(5), 867-871.

(iD) : https://orcid.org/0000-0002-4096-1979

(iD): https://orcid.org/0000-0003-1937-7708

* (iD : https://orcid.org/0000-0002-0870-5094

*Corresponding author's:

Mahmut M. BAYRAMOĞLU

Karadeniz Technical University, Department

of Forest Engineering, Kanuni Campus,

Trabzon, Turkey.

凶: mahmud@ktu.edu.tr

Mobile telephone: +90 (533) 5596093

Telephone $\quad:+90(462) 3774143$

Fax : +90(462) 3257499

Abstract: Wood Pellet, one of the biomass fuels in renewable energy sources, stands out among all renewable energy sources with it's ease of production technology, environmental friendliness and similar features. Wood pellets, which are fuel pellets of 6-10 $\mathrm{mm}$ diameter, which are obtained from the drying of wood waste, milling it into sawdust and then compressing it with high pressure, have become economically comparable with fossil fuels today. Wood pellet trade worldwide increased by more than $21 \%$ in 2018 compared to the previous year, reaching a trade volume of 22.3 million tons. The biggest pellet exporter countries in the world since 2012 are USA, Canada, Vietnam, Latvia and Russia respectively. These countries accounted for approximately $69 \%$ of the world export volume in 2018. Except for five countries, they continue to work on alternative energy sources and especially the production, technology, use and properties of wood pellets in China. In Turkey, there are studies on the production of wood pellets and the economy. However, these studies need to be updated both in terms of production and economics. In the study, analyzed the current data with the potential that Turkey has developed proposals for the use of this potential.

Keywords: Forestry, economy, biofuel, energy demand.

\section{Türkiye’nin Biyokütle Enerji Potansiyeli Üzerine Bir Araştırma: Odun Peleti Örneği}

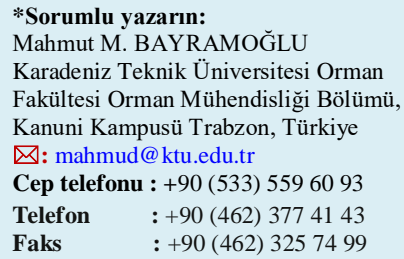

Öz: Odun Peleti, üretim teknolojisi kolaylığı, çevre dostu olması ve benzeri özellikleri ile tüm yenilenebilir enerji kaynakları içinde öne çıkmaktadır. Odun artıklarının kurutulup, ögütülerek talaş haline getirildikten sonra yüksek basınçla sıkıştırılmasından elde edilen 6-10 mm çapındaki yakıt topakları olan odun peletin ekonomik açıdan günümüzde fosil yakıtlar ile karşılaştırılabilir konuma gelmiştir. Dünya genelinde odun peleti ticareti, bir önceki yıla kıyasla 2018' de \% 21'den fazla artış göstermiş olup 22.3 milyon tonluk ticaret hacmine ulaşmıştır. Dünya'da 2012 yılından itibaren en büyük pelet ihracatçısı ülkeler sırasıyla ABD, Kanada, Vietnam, Letonya ve Rusya'dır. Bu ülkeler 2018 yılında dünya ihracat hacminin yaklaşık\% 69'unu oluşturmuşlardır. Beş ülke haricinde Çin'de alternatif enerji kaynakları ve özellikle odun peletinin üretimi, teknolojisi, kullanımı ve özellikleri üzerine çalışmalarını devam ettirmektedirler. Türkiye'de ise odun peletinin üretimi ve ekonomisi üzerine çalışmalar bulunmaktadır. Ancak bu çalışmalar gerek üretim gerekse ekonomik açıdan güncellenmesi gerekmektedir. Çalışmada, Türkiye'nin sahip olduğu potansiyel güncel veriler ile analiz edilerek bu potansiyelin kullanımına yönelik öneriler geliştirilmiştir.

$\underline{\text { Anahtar kelimeler: Ormancılık, ekonomi, biyo-yakıt, enerji talebi. }}$ 


\section{INTRODUCTION}

Renewable sources particularly biomass account for an increasing proportion of energy generation. Efforts to limit the use of fossil fuels and the development of alternative energy resources are also effective in this increase (Kaygusuz et al., 2017). Wood pellets are the most popular and traded among biomass fuels (Jagers et al., 2020). Wood pellets from biomass fuels have emerged as a substitute for coal, natural gas and fuel oil both in industry and residential heating (Junginger et al. 2019). Wood pellet is obtained by smashing and compressing the wood residuals such as wood chips and tree bark. Sawdust or wood chips that are compressed under high temperature and pressure bind together, due to their lignin content, to form wood pellet. Wood pellet, which is a subsidiary product obtained from sawdust as a result of wood processing, can now also be obtained from round chocks and battens. Wood pellet is highly preferable to other solid biomass fuels due to its low humidity (less than 10\%) and high energy density (Junginger et al., 2011; Stewart, 2006).

Compared to wood pellets to produce $1 \mathrm{MWh}$ of energy; natural gas 3, fuel oil 5 and electric heating release 10 times as much $\mathrm{CO}_{2}$ into the atmosphere (Saraçoğlu, 2010). For this reason, the production and use of wood pellets is increasing, especially in developed countries Many countries have made legal regulations on the use and trade of wood pellets in response to this interest (Bayramoğlu \& Toksoy, 2015).

The use of renewable energy sources in Turkey has not yet reached the desired level. The use of fossil fuels in industry and residences is quite high. The share of the overall power generation of renewable energy sources, despite a great potential to renewable energy sources is low in terms of Turkey. There has been an increase in energy production from renewable energy sources with the legal regulations (subsidy etc.). Turkey's energy potential of biomass is also high. However, the use and trade of this potential is almost nonexistent. The reason for this situation; Inadequate studies on biomass fuels (especially wood pellets), lack of a market for biofuels produced from wood raw materials, lack of legislation, and not encouraging private sector investments.

Turkey's biomass potential has been demonstrated with this study with updated data compared with other energy sources of wood pellets. The amount of wood pellets that can be produced and its economic value have been calculated.

\section{MATERIALS AND METHOD}

Data Collection: In the study, many studies in the literature on climate change, biomass energy and wood pellet and international conventions, protocols, meeting and conference final declarations related to the emergence and functioning of wood pellet were also used as material. Especially in Turkey, biomass potential and wood pellet, use, trade, legal and institutional report prepared by the relevant ministries for the section dealing with regulations, national action plans and strategy documents were also used.

Methods: Literature review method was used in the study. Detailed information on the subject was obtained and analyzed. The deductive method was used to form the conceptual framework of the study. First of all, the concepts of renewable energy, biomass energy and wood pellet were introduced and wood pellet formed as a result of international processes were explained. Also next to the position of Turkey in the wood pellet market, the situation in the international process, scientific and technical infrastructure and legal and institutional arrangements were discussed.

\section{RESULTS AND DISCUSSION}

Biomass Energy Potential of Turkey: Turkey has a significant amount of biomass and bioenergy potential. However, there are different studies regarding the total bioenergy potential. Turkey's total bioenergy potential was estimated Taşdemiroğlu (1986) 17 Mtoe (million tonnes of oilequivalent), WECTNC (1996) 16.92 Mtoe, Ediger and Kentel (1999) 17.2 Mtoe, Kaygusuz (2002) 16.9 Mtoe, Demierbaş et al. (2006) 65 Mtoe, Toklu (2017) 17 Mtoe and Öztürk et al. (2017) 16.92 Mtoe.

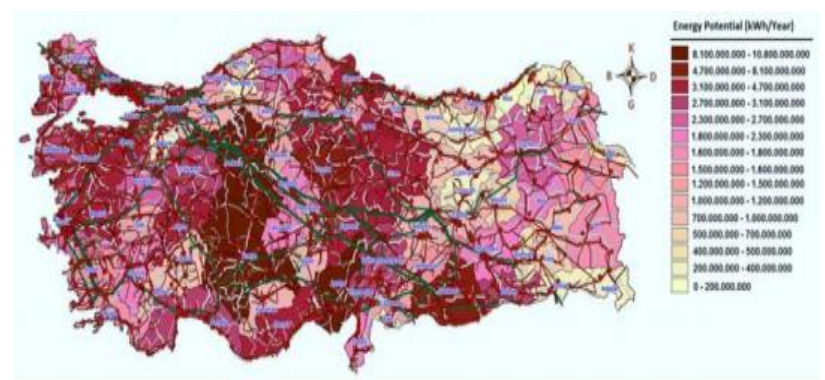

Figure 1. Turkey's total biomass potential (MEF, 2009).

Turkey's main biomass production is given in Table 1. Turkey's main biomass production is based on wheat straw, wood and woody materials, cocoon shell, hazelnut shell, grain dust, crop residues and fruit tree residues (Melikoğlu, 2013). Various agricultural residues such as grain dust, wheat straw and hazelnut shell are available in Turkey as the sources of biomass energy. Approximately $2.6 \times 10^{7}$ tonnes of wheat straw was produced annually in Turkey. The straw is disposed of in the fields either by burning or sometimes by ploughing it back into the soil. Because the higher heating value of 
straw is about $1 / 2$ that of high-grade coal (its higher heating value is about $28 \mathrm{MJ} / \mathrm{kg}$ ), the surplus straw is equivalent to about $1.3 \times 10^{7}$ tonnes. The hazelnut shell is a potentially important energy source and the amount produced annually in Turkey is estimated to be about $3.5 \times 10^{5}$ tonnes. The higher heating value of the hazelnut shell is $19.2 \mathrm{MJ} / \mathrm{kg}$ and its calorific value is equivalent to about $1.9 \times 10^{6} \mathrm{kWh}$ (Demirbaş \& Şahin, 1998; Sürmen, 2002).

Table 1. Turkey's annual biomass potential (İlleez, 2020).

\begin{tabular}{lccc}
\hline & $\begin{array}{c}\text { Amount } \\
\text { (tone/year) }\end{array}$ & $\begin{array}{c}\text { Energy } \\
\text { Potential } \\
\text { (TEP/year) }\end{array}$ & $\begin{array}{c}\text { Economical } \\
\text { Energy Potential } \\
\text { (TEP/year) }\end{array}$ \\
\hline Animal wastes & 193.878 .079 & 4.385 .371 & 1.084 .506 \\
Agricultural residues & 62.206 .754 & 6.009 .049 & 1.462 .159 \\
City residues & 32.170 .975 & 3.373 .011 & 485.858 \\
Forest residues & 2.739 .865 & 859.899 & - \\
TOTAL & $\mathbf{2 9 0 . 9 9 5 . 6 7 3}$ & $\mathbf{1 4 . 6 2 7 . 3 3 0}$ & $\mathbf{3 . 0 3 2 . 5 2 3}$ \\
\hline
\end{tabular}

Turkey's electricity generation in the year 2018 $303.625 \mathrm{GWh}$ (26 million toe) $68 \%$ of this production is from fossil sources, $32 \%$ is produced from renewable energy sources. However, the share of biomass in renewable energy remained at a very low level with a share of $2.75 \%$ and $0.88 \%$ in total electricity generation (İlleez, 2020). In 1990, the heat produced from biomass sources worldwide was realized as 6.2 million TEP and met only $1.6 \%$ of the total heat production. In 2018, heat production from biomass reached $7.5 \%$ with 26 million TEP. Europe is the world leader with $87 \%$ share of heat generated globally due to its widespread and effective use of all biomass resources, including municipal waste, solid biofuels and industrial waste (WEO, 2019). Turkey at the end of 2018 the production of heat energy biomass has had a $10.2 \%$ share by approximately 133.000 TEP (IEA, 2020; ETKB, 2020; IRENA, 2019).

Table 2. Present and planned biomass energy production in Turkey (SSI, 1996).

\begin{tabular}{lccc}
\hline Years & Modern Biomass (ktoe) & Classic biomass (ktoe) & Total (ktoe) \\
\hline $\mathbf{1 9 9 9}$ & 5 & 7012 & 7017 \\
$\mathbf{2 0 0 0}$ & 17 & 6965 & 6982 \\
$\mathbf{2 0 0 5}$ & 766 & 6494 & 7260 \\
$\mathbf{2 0 1 0}$ & 1660 & 5754 & 7414 \\
$\mathbf{2 0 1 5}$ & 2530 & 4790 & 7320 \\
$\mathbf{2 0 2 0}$ & 3520 & 4000 & 7520 \\
$\mathbf{2 0 2 5}$ & 4465 & 3345 & 7810 \\
$\mathbf{2 0 3 0}$ & 4895 & 3310 & 8205 \\
\hline
\end{tabular}

Since the early 2000s, it has prepared the biomass energy production program in Turkey. Present and planned biomass energy production in Turkey is given in Table 2. According to a study by Demirbaş (2006), Turkey's biomass production was 7 million tonnes in 1999, and is predicted to increase to 8.2 million tonnes in 2030 . According to the index published by Ernst \& Young (2012), Turkey is ranked 30th of 40 countries (index value
39.8) for renewable energy and 28th for biomass (index value 35$)$.

Wood and Woody Biomass Potential of Turkey: Interest in forests is increasing, especially due to its role in carbon sequestration in mitigation global climate change. In order to reduce the greenhouse gas accumulation of forests; It is necessary to protect forests, planting new forest areas, reducing harvest density, increasing forest growth and carbon storage in harvested wood products (Bilgen, 2014).

Woody biomass (especially fuelwood), as in the world, it is important for rural areas in Turkey because fuelwood is very important source of energy and the major source of energy in rural T urkey. About half of the world's population rely on woody biomass or other biomass for cooking and other domestic use.. About half of the total demand for fuelwood is met through informal cutting of State forests and other woody biomass resources in agricultural areas (Bilgen et al., 2008). Among the biomass energy sources, woody biomass is the most interesting. Because it is high in Turkey's total energy production and conversion techniques are useful to it is not necessarily complicated. Forest biomass consumption compared to total energy has decreased from $22 \%$ to $14 \%$ (Kaygusuz, 2010).

The latest data of the forest assets in Turkey published in 2015. Turkey's forest area of 22,342,935 hectares have been based on these data in 2015. Turkey forest area constitutes $29 \%$ of the 78 million hectares of the country up to the surface. According to 2015 data, $57 \%$ $(12,704,148 \mathrm{ha})$ of forest areas are forest areas with more than $10 \%$ canopy cover, which is qualified as productive forest in terms of wood raw material production. The remaining $43 \%$ of the forest areas $(9,638,787$ ha) consists of hollow closed forest areas with a closure less than $10 \%$ and called degraded or inefficient forest areas. The total forest potential of Turkey is around 1.6 billion $\mathrm{m}^{3}$ with an annual growth of about 45.9 million $\mathrm{m}^{3}$ in 2015 (TOD, 2019).

Table 3. Turkey's 2015-2019 industrial and firewood production.

\begin{tabular}{lcc}
\hline Years & Industrial Wood $\left(\mathbf{m}^{\mathbf{3}}\right)$ - & Firewood (Stere) \\
\hline $\mathbf{2 0 1 5}$ & 16.637 .598 & 5.022 .986 \\
$\mathbf{2 0 1 6}$ & 17.009 .998 & 4.877 .067 \\
$\mathbf{2 0 1 7}$ & 15.521 .622 & 4.359 .646 \\
$\mathbf{2 0 1 8}$ & 19.080 .137 & 4.890 .455 \\
$\mathbf{2 0 1 9}$ & 22.113 .248 & 5.589 .798 \\
\hline
\end{tabular}

Turkey has produced 22.3 million $\mathrm{m}^{3}$ industrial wood and 5.58 million stere firewood in 2019. Turkey's 2015-2019 industrial and firewood production are given in Table 3 . In the last 5 years, it has produced an average of 18.072.520,6 $\mathrm{m}^{3}$ industrial wood and 4.947.990,4 stere firewood. 
Wood Pellet Potential of Turkey: The forestry sector is a rising trend in Turkey. In order to meet the demand of the sector, industrial wood production has been increased by approximately $33 \%$ in the last 5 years. Approximately $25 \%$ of a tree is left in the forest as production residue at the end of the production activity (Karayilmazlar et al., 2011). In Turkey, annually about 5 million $\mathrm{m}^{3}$ wood residues is left in the forest. These residues are left to rot as they do not set off the transportation costs. There are different studies on the amount of production residues. Bayramoğlu and Toksoy (2015) stated that approximately 4 million $\mathrm{m}^{3}$ of forest residues could be obtained from 10 million $\mathrm{m}^{3}$ of industrial wood production. According to General Directorate of Forestry (GDF) estimated that there was a total of 3.528.320 stere of production residues in 27 Regional Forest Directorates (RFD) between 2007 and 2009.

Assuming that $1 \mathrm{~m}^{3}$ is equal 0.600 tone, 5 million $\mathrm{m}^{3}$ wood is equal to 3 million tone. Approximately $600 \mathrm{~kg}$ wood pellet is produced from 1 tone wood. In this context 1.8 million tone wood pellet can be produced from 3 million tone wood which market value nearly 274 million dollar. The energy value that can be obtained from 1.8 million tonnes of wood pellets is approximately 0.72 Mtep which represents $0.57 \%$ of total primary energy consumption in 2015 , and $0.75 \%$ of the imported amount of energy (95.1 mtep); $0.54 \%$ of total primary energy consumption in 2016 and $0.74 \%$ of imported energy (97.3 mtep); $0.49 \%$ of total primary energy consumption in 2017 and $0.65 \%$ of imported energy (110.1 mtep) of TurkeyFrom 2015 to 2017, Turkey paid 37.8, 27.1 and 37.2 billion dollars, respectively for imported energy. According to these calculations, if Turkey utilized wood pellet potential, this would result in saved of 28.3 billion dollars in 2015, 20 billion dollars in 2016 and 24.1 billion dollars in 2017.

Economic comparison of the Turkish context indicates that wood pellet is more advantageous than other energy sources. One house in Turkey requires approximately 50.2 GJ heating energy, which would require 2 tonnes of coal, $1142 \mathrm{~kg}$ oil fuel, $1454 \mathrm{~m}^{3}$ natural gas or 2.66 tonnes wood pellets.

Table 4. Compare of Energy Sources.

\begin{tabular}{lllll}
\hline Energy Sources & Energy $(\mathrm{kcal})$ & Amount $(\mathrm{kg})$ & Unit Price $(\$)^{* *}$ & Total $(\$)$ \\
\hline Coal & 6000 & 2000 & 0.28 & 560 \\
Fuel Oil & 10500 & 1142 & 0.47 & 541 \\
Natural Gas & 8250 & $1454^{*}$ & 0.31 & 450 \\
Wood Pellet & 4500 & 2660 & 0.14 & 371
\end{tabular}

*Amount of Consumption calculated $\mathrm{m} 3$ for natural gas $* * 19.09 .2020$ date $1 \$=7.90$ TL exchange rate.

Wood pellet has lower energy value than other energy sources because it has lower energy density (18 $\mathrm{MJ} / \mathrm{kg}$ ) . However, this low energy value and high rate of usage means that wood pellet is cheaper than other energy sources.

In 2017, approximately 23.8 million tone of wood pellets were traded in the world. In 2023, this trading volume is expected to be 29 million tone. The use of wood pellets in developed countries has increased. In 2018, Japan imported over 1 million tone, South Korea 3.4 million, Netherlands 2.5 million and United Kingdom 1.5 million tone of wood pellets. Unfortunately, there is not data on the wood pellet trade in Turkey. If Turkey uses the potential of wood pellet, it is inevitable that it will get a share of the international market.

In this study, Turkey's wood pellet potential was calculated at 1.8 million tone, while Bayramoğlu and Toksoy (2015) calculated approximately 400,000 tone. Although the value of wood pellet is calculated as \$274 million, Bayramoğlu and Toksoy (2015) stated that this value as $\$ 586$ million. This difference is due to the change in the amount of wood used in production and the dollar rate. Besides, Bayramoğlu and Toksoy (2015) stated that wood pellet is more economical than other energy sources.

\section{CONCLUSION}

As a result of the increase in energy prices in the world, events in energy supply security, the development of alternative energy sources and the legal regulations and policies to reduce the use of fossil fuels in the combat against climate change, the share of renewable energy sources, especially biomass fuels, in energy production is increasing. Wood pellet is a prominent product in biomass fuels due to its ease of production and high raw material potential. Although legal regulations on renewable energy have been made in Turkey, the wood pellet has been in lower demand than expected, especially due to high costs.

Turkey should try to raise more awareness about its bioenergy potential. Legal arrangements must be made to create a market for wood pellets. Private sector investments should be encouraged, and national production standards should be created.

\section{ACKNOWLEDGMENTS}

The authors declare that there are no conflicts of interest. This study was presented in ORENKO 2020 held by Karadeniz Technical University, Trabzon.

\section{REFERENCES}

Bayramoğlu, M.M. \& Toksoy, D. (2015). Economic evaluation of wood pellet as a renewable energy source in Turkey, In: Efe, R., Curebal, İ., Bizzarri, C. \& Nyussupova, G. (Ed), Environment and ecology at the beginning of the 21st century. 125- 
137 p, St. Klıment Ohrıdskı Unıversity Press, Sofia, Bulgaria.

Bilgen, S., Keleş, S., Kaygusuz, A., Sarı, A. \& Kaygusuz, K. (2008). Global warming and renewable energy sources for sustainable development: A case study in Turkey. Renew Sustain Energy Rev., 12(2), 372-396.

Bilgen, S. (2014). Structure and environmental impact of global energy consumption. Renew Sustain Energy Rev., 38, 890-902.

Demirbaş, A. \& Şahin, A. (1998). Evaluation of biomass residue 1 . briquetting waste paper and wheat straw mixtures. Fuel Processing Technology, 55(2), 175-183.

Demirbaş, A. (2006). Turkey's renewable energy facilities in the near future. Energy Sources, Part A, 28(6), 527-536.

Demirbaş, A., Pehlivan, E. \& Altun, T. (2006). Potential evolution of Turkish agricultural residues as biogas, bio-char and bio-oil sources. Int J Hydrog Energy, 31, 613-620.

Ediger, V.Ş. \& Kentel, E. (1999). Renewable energy potential as an alternative to fossil fuels in Turkey. Energy Convers Manag, 40, 743-755.

Ernst. \& Young. (2012). Renewable energy country attractiveness indices. London, UK, 44p.

ETKB. (2020). Ulusal Enerji Denge Tablolar1, https://www.eigm.gov.tr/tr-TR/DengeTablolari/Denge-Tablolari. (03 Mart 2020).

IEA. (2020). İstatistik Verileri. https://www.iea.org/dataand-statistics. (03 Mart 2020).

IRENA. (2019). Renewable Energy Statistics 2019, The International Renewable Energy Agency, Abu Dhabi. ISBN 978-92-9260-137-9.

İleez, B. (2020). Türkiye'de Biyokütle Enerjisi. Türkiye'nin Enerji Görünümü 2020, TMМOB Makina Mühendisleri Odası, Ankara, 317- 344.

Jagers, J., Spayz, P., Wirtz, S. \& Scherer, V. (2020). Analysis of wood pellet degradation characteristics based on single particle impact tests. Powder Technology (in press).

Junginger, M., Van Dame, J., Zarrilli, S., Mohamed, F.A. Marchal, D. \& Faaij A. (2011). Opportunities and Barriers For International Bioenergy Trade. Energy Policy, 39(4), 20282042.

Junginger, H.M., Mai-Moulin, T., Daioglou, V., Fritsche, U. et al. (2019). The future of biomass and bioenergy deployment and trade: a synthesis of 15 years IEA Bioenergy Task 40 on sustainable bioenergy trade. Biofuels, Bioproducts and Biorefining, 13(2), 247-266.

Stewart, A. (2006). Small-Scale Pellet Production. Presented At: Wood Pellet Fuel Production, Milton Keynes.

Karayılmazlar, S., Saraçoğlu, N., Çabuk, Y. \& Kurt, R. (2011). Using of biomass in energy generation in Turkey. Bartın For. Fac. Mag., 13, 19-75.

Kaygusuz, K. (2002). Sustainable development of hydropower and biomass energy in Turkey. Energy Convers Manag, 43, 1099-1120.

Kaygusuz, K. (2010). Energy services and energy poverty for rural regions. Energy Sources Part B, 5, 424433.

Kaygusuz, K., Toksoy, D. \& Bayramoğlu, M.M. (2017). Global utilization of wood pellet for residential heating. Journal of Engineering Research and Applied Science, 6(2), 688-697.

MEF. (2009). Forest biomass situation for renewable energy in Turkey. Ministry of Environment and Forestry, Ankara, 2009.

Melikoğlu, M. (2013). Vision 2023: Feasibility analysis of Turkey's renewable energy projection. Renew Energy, 50, 570-575.

Öztürk, M., Saba, N., Altay, V., Iqbal, R. et al. (2017). Biomass and bioenergy: An overview of the development potential in Turkey and Malaysia. Renewable and Sustainable Energy Reviews, 79, 1285-1302.

Saraçoğlu, N. (2010). Küresel İklim Değişimi, Biyoenerji ve Enerji Ormancılı̆̆l, Efil Yayınevi, Ankara, Türkiye, 300p.

SSI. (1996). State Statistics Institute. Environmental Statistics. Environment Inventory for Municipalities, Ankara, Turkey.

Sürmen, Y. (2002). The necessity of biomass energy for Turkish economy. Energy Education Science and Technology, 10, 19-26.

Taşdemiroğlu, E. (1986). Biomass energy potential in Turkey. Biomass, 11(1986), 81-89.

Toklu, E. (2017). Biomass energy potential and utilization in Turkey. Renewable Energy, 107, 235-244.

WECTNC. (1996). Turkey Energy Report-1995. World Energy Council-Turkish National Committee, Ankara.

WEO, (2019). Global Bioenergy Statıstıcs 2019. World Bioenergy Association, Chicago, USA, 58p. 